УДК $78.03+782.1$

\title{
Чжан Кай
}

\section{РЕПЕРТУАРНОСТЬ КАК КРИТЕРИЙ СОВРЕМЕННОЙ ОПЕРНОЙ ПРАКТИКИ}

\begin{abstract}
Предлагается рассматривать оперный репертуар как необходимую основу деятельности современного оперного театра, находить в понятии репертуара ведущую категорию опероведения. Определяются репертуарные константы современного оперного творчества, традиционные и инновационные направления оперного репертуара. Выводится критерий репертуарности как показатель успешности оперной творческой практики.
\end{abstract}

Ключевые слова: оперный театр, современная оперная практика, репертуар, опероведение, репертуарные инновации.

Оперный театр является особым феноменом мировой культуры, позволяющим создавать прочные условия для ее духовного художественного единства. На его основе осуществляется широчайший синтез художественно-языковых форм, направлений художественной деятельности, социальных и индивидуальных творческих идей. Основой данной универсальности оперного театра как целостного творческого феномена становится репертуар как общая программа художественной жизни театра и выражение его жанрово-стилевых интересов. В истории европейского оперного театра выработались и к началу текущего столетия достаточно четко определились совокупные показатели той репертуарной экспозиции оперно-театрального художественного феномена, которая, во-первых, свидетельствует о его профессиональной зрелости и прочности, во-вторых, соответствует современному положению оперного жанра в мировой культуре, в-третьих, воспроизводит эстетические паттерны художественного сознания, вне которых оно не может сохраняться и развиваться далее.

Главной причиной написания данной статьи явился тот факт, что европейская опера в ее репертуарных образцах и показателях заняла прочное место в творческой системе китайских оперных театров, поэтому важно определить, что позволяет ей становиться классической основой мирового оперного искусства и необходимой базой для взращивания национального оперного стиля. Задачей нашей работы является определение тех художественно-эстетических факторов европейской оперы, которые позволяют ей в отдельных образцах воздействовать на репертуарные критерии оперно-театральной деятель-

(C) Чжан Кай, 2014 
ности, выводить понятие репертуарности в один ряд с категориями художественной значимости и эстетической ценности.

В исследовании В. Богатырева [1] специально подчеркивается, что центральной фигурой, олицетворяющей подлинное взаимодействие частей в явлении оперного целого, является певец-актер, поскольку в своем идеальном воплощении это и совершенный музыкальный инструмент, и мастер художественного слова, и мастер сценической пластики. Вместе с тем тот функциональный синтез, который обнаруживает искусство оперного певца, обусловлен единым синкретическим - синтетическим - симбиотическим характером оперного действия, жанровой формы оперы во всех ее исторических разновидностях.

В. Богатырев выделяет в качестве магистрального направления формирования данного особого сложного характера оперы драматическое начало, полагая, что опера всегда строится на тезе и антитезе, предусматривает изображение конфликтов, то есть действий, наталкивающихся на противоборство, на контрдействие, из этих действий выводя принципы музыкальной драматургии, то есть совокупность тех приемов, которые позволяют музыке эмоционально-психологически выверять структуру драматического действия собственными средствами. По мысли данного автора, однако, для рождения «оперной пьесы», то есть партитуры спектакля, необходимо, как непременное условие, вербальное описание и действия и персонификация конфликта.

Любая опера обладает двумя текстами - музыкальным и поэтическим. Они органично соединяются в партии-роли, когда на оперной сцене данную роль исполняет певец-актер. Вне вокальной партии вербальное описание спектакля полностью утрачивает свою оперную художественную семантику, то есть словесный текст в опере должен входить в единство с музыкальным звучанием, а посредством музыки солидаризоваться с содержанием сценического действия.

Словами В. Богатырева, теория театра, «подарившая» театру понятие драматического действия, приносит его и в стихию оперной музыки. Для данного действия стержневым началом является сюжет с его фабульной стороной и приемами остраннения материала фабулы [1].

В опере только слово, структурирующее чувственную стихию музыки и описывающее конфликт, даёт возможность пространственного выражения сюжета, конкретности действия - саму возможность 
сценического существования персонажа оперной партитуры. В таком ракурсе следует предположить, что априорно утвердившиеся в искусствоведении воззрения на оперу как на искусство синтетическое требуют уточнений. Причем нельзя не согласиться с В. Богатыревым в том, что даже если первоисточник повествует о переживаниях, эмоциональных реакциях, «полон интеллектуальных обобщений и полифонических взаимоотношений персонажей», классическая опера всегда стремится остаться драмой «аристотелевского типа» эпически целостной и эстетически определенной. Однако, каким образом это осушествляется в опере, на каких исторических жанровых основаниях, и что позволяет эпической опере оставаться тем стилевым палимпсестом, который обеспечивает проступание эпических черт оперного жанра даже в значительно более поздних и иных по эстетическому призванию оперных композициях? В исследовании В. Богатырева мы не находим ответов на данные вопросы, поэтому попробуем открыть их возможность в изучении исторических оснований и фундаментальной эстетической презумпции оперы.

Анализ художественного содержания оперы как целостного синтетического жанра обнаруживает ее прочную связь с античной трагедией и трагическим как формой художественно-эстетического отношения. Эта связь нуждается в специальном изучении, потому что пути формирования и развития трагической семантики в опере являются сложными и неоднозначными. Кроме того, они специфичны именно для европейской культуры, европейского типа мышления, а потому должны внимательно рассматриваться китайскими вокалистами, исполняющими партии в операх европейских композиторов.

Хотя о влиянии античного греческого театра на развитие оперы уже писалось, основные вехи этого влияния на всем историческом пути оперы (а не только в момент ее зарождения) еще не прослежены. Знание этих путей позволяет правильно интерпретировать не только сюжет и мотивы поведения оперных героев, не только либретто и возможности сценографии, но и конкретные музыкально-композиционные решения, ключевые музыкальные темы, способы интонирования.

Трагедийная опера является центральной жанровой разновидностью оперы потому, что она выросла на основе эпического греческого театра, а на ее основе может быть предложена историческая и семантическая типология репертуара европейской оперы, поскольку она так или иначе всегда направляет эволюцию жанровой формы оперы. 
Античная трагедия стала истоком оперы по многим признакам: образно-смысловым содержательным, структурно-композиционным, исполнительским сценографическим. Но главное, что связывает античный театр и музыкальный театр Нового времени, - идея борьбы человека за власть над временем, что означает - и за власть над миром. В этой борьбе постоянным соперником человека становится Рок - те силы судьбы, которые превосходят силы и способности человека. Античная тематика определила формирование оперного содержания, оперных сюжетов и, в конечном счете, оперного репертуара.

Будучи связанной с проблемой трагедии, трагического театра - в том числе трагического музыкального театра, античная тема охватывает достаточно широкий диапазон вопросов и явлений. Ее достаточно общее значение для последующих культур объясняется тем, что искусство Древней Греции образует первый исторический этап в развитии европейского художественного мышления, и именно в нем, по давно сложившемуся мнению, следует искать истоки поэтики всего европейского искусства.

Кроме того, дистанцированность взгляда на античность позволила своеобразно эстетизировать, идеализировать дохристианскую культуру, представлять ее в качестве эталона духовности. Возрождение интереса к античной теме в двадцатом веке оказалось связано с поиском «вечных», архетипических сюжетов и образов в искусстве, что и данную (античную) тему заставило представлять как апеллирующую к таким сюжетам, образам.

Проблема античности в широком ее понимании может рассматриваться (и такие тенденции существуют в ведущих искусствоведческих трудах по данной проблеме) с двух основных позиций: исторической (историко-хронологической) и культурологической (семантико-типологической). Уже благодаря первой позиции «античную тему» связывают не только с использованием определенных мифологических сюжетов, впервые замеченных древними авторами, но и с более общими явлениями взаимодействия поэзии и музыки, с философскими идеями и традицией гуманистической мысли в целом, с идеями гармонии-калокагатии и т. д. Вторая позиция позволяет обнаруживать связь античной темы как исторически протяженного культурологического феномена и явления трагедийности. Трагедийность, когда ее связывают с античным театром, эстетики и культурологи обычно рассматривают, не выходя за пределы древнегреческого театра, то есть 
преимущественно как особый обрядовый, ритуальный, синкретический феномен.

С музыковедческих позиций заметно, что в возникновении и развитии оперы наибольшую важность приобретает соединение мифологического сюжета и трагедийной интерпретации. Благодаря этому в европейскую музыку в целом входит «тема Рока». Она унаследована от античной трагедии благодаря синтезу в ней мифологической формы и психологически заостренного трагедийного содержания. Последнее особенно интересно для формы оперы как музыкального жанра и способствует становлению различных типов оперной композиции, музыкально-интонационной выразительности, а также взаимосвязано с различными стилевыми тенденциями в эволюции жанровой формы оперы.

В связи с определением основных тенденций взаимодействия «античной темы» с композиционно-стилевыми условиями оперы возникает необходимость определения черт и тем греческого театра в целом - тех, которые впоследствии получат определение «классические» и будут интерпретироваться и преломляться в жанре оперы. При выявлении особенностей античной драмы следует исходить из такой важной ее особенности, как двойственность, наличие двух путей решения конфликта: эпического и лирического, посредствующими звеном между которым является драматическое действие, вернее, то действие, в котором начинают распознавать черты драмы.

Определение значений этой двойственности, раскрытие особенностей каждой из двух интерпретаций, прослеживание их последующего размежевания возможно путем обобщенной характеристики ранней барочной оперы, классицистской (от seria до Х. Глюка), а также путем более детального анализа оперных сочинений К. Монтеверди, Г. Перселла, А. Онеггера, композиторов русской школы Н. Римского-Корсакова и С. Танеева, существенно углубляют представления об исторически-процессуальном способе формирования эстетических принципов оперного жанра.

Предназначение эпоса, благодаря которому память о нем хранится во всех производных, более поздних, оперных жанровых формах, связано с открытием эстетической целостности и упорядоченности оценочного человеческого опыта, внутри которой содержатся предпосылки более конкретных этических и психологических рефлексирующих отношений. Последние составляют специальную предмет- 
ную область драматического и лирического направлений в эстетике и поэтике оперного театра. Континуальности, обобщенности эстетических состояний противостоит дискретность познавательно-этических подходов, конкретный и единичный характер личностных самооценок. Со стороны их психологической знаковости ведущими становятся представления о добре - зле, силе - слабости, уверенности - страхе, любви - ненависти (доверии - ревности, тревоге), некоторые другие. В отличие от эстетических антиномий, открывающихся эпическому сознанию, данные антиномичные пары, реализуя драматические и лирические установки, тяготеют к обострению противоречий, к неизгладимости антиномичного напряжения, к дисгармоничному перевесу условно-негативной стороны антиномии. Как драматическое, так и лирическое всегда чреваты трагедийными осложнениями и подразумевают последние - даже когда демонстрируют их преодоление, ибо такое преодоление так или иначе раскрывается как временное. Действительное и действенное снятие самопротиворечивости антиномии возможно только при достижении «психологического синтеза» эпического масштаба, то есть при привлечении совершенного всеединства жизни и знания о таком совершенстве... (см. об этом: [3])

Однако у драматического и лирического направлений в искусстве есть свои преимущества, а именно: во-первых, они позволяют укрупнить, приблизить индивидуально-неповторимое, уникальное в творческом, в том числе - психологически-творческом опыте человека; во-вторых, они усиливают самоценность художественной формы, собственно, превращают ее в «артефакт», в инициативное направляющее начало культуры. Только лирический (неизбежно становящийся драматическим) автор становится в полной мере «первым лицом», от имени и по воле которого строится художественная форма, а потому «фоновым» материалом для такого автора становится он сам его способности к пониманию - самопознанию и сооценке своего и чужого психологического «хождения в реальность». Буквальное сокрашения масштабов лирической формы соответствует сужению интересующей автора предметной области - от макромира всеединой жизни до микрокосма личностного сознания, однако такое сокращение - сужение требует новой смысловой глубины формы, приращивания и преобразования, то есть количественного и качественного изменения содержательных функций знака. Лирическая форма всегда тяготеет к символичности, идущей от глубинных знаковых струк- 
тур личностного сознания и ярко демонстрирующей катарсическую направленность данного сознания.

Катарсис - тот психологический эффект, который обязательно сопутствует художественному воздействию и свидетельствует о его достаточной эстетической глубине. Его истоки также связаны с греческой культурой, в частности, с очистительными функциями обрядовой практики и театральных действий, обнаруживающих обусловленность идеей жертвы и жертвенности. В данной системе очистительной практики представлен особый тип жертвы - жертвысвидетели, люди, которые в силу особой духовной одаренности, говоря словами Павла Флоренского, способны свидетельствовать истину и бороться за нее любой ценой, бороться радостно, не побоявшись отдать собственную жизнь. Такое понимание жертвенности в дальнейшем перейдет в христианскую религию (возможно, не только в христианскую), но оно переходит и в античную греческую идею рока, которая определяет главное содержание древней трагедии, а затем опер трагедийно-эпической направленности [6].

Связь идеи рока с представлениями о судьбе «мирового Разума» Нуса подчеркивает целесообразность ноологической трактовки катарсиса, предложенной А. Лосевым и наиболее близкой, как кажется, к символической сложности этого понятия [5]. Лосев выходит за пределы «Поэтики» и замечает, что понятие об очищении у Аристотеля тесно связано с представлениями о саморазвитии Нуса, а отсюда - с понятиями о мимезисе (подражании, ключевом для всей эстетики Аристотеля), благе, радости («безвредной радости», как обозначает ее философ в «Политике»), самодовлеющем наслаждении (блаженстве, которое есть высшее из всех доступных человеку чувств, поскольку даровано прикосновением к Нусу). Главное в ноологической версии катарсиса по Лосеву то, что цепь трагедийных событий - собственно трагедия - оказывается лишь одним эпизодом - этапом в катарсическом самодвижении Мирового Разума. Одновременно весь мир оказывается трагическим целым, и от трагического в широком его понимании просто некуда уйти... Человек существует «в зоне постоянного напряжения», «между Вечностью и жизненной детерминированностью смертного человека» (М. Бахтин [2]). Это и есть доступный человеку эстетический - чувственно-духовно обобщающий - опыт. На трагедийном этапе Нус саморазрушается, самооскверняется какими-то наиболее трудными и противоречивыми реалиями жизни; но это саморазрушение - искажение первоначальной 
чистоты Нуса - становится предпосылкой нового обретения целостности и чистоты. С этого (трагедийного) момента, как с точки самой глубокой потери себя, начинается возвращение Нуса к самодавлеющему блаженству, катарсическое восстановление.

Ноологическая концепция катарсиса позволяет понять, что сложное символическое содержание «очищения» нельзя найти только в самой трагедии. Катарсис подготовлен трагедией, но совершается за ее пределами - можно сказать, даже вопреки трагедии. Не случайно его содержание определяется такими эстетическими категориями, как Прекрасное (Красота), Добро, Свет, Гармония, выступающими оппозицией катастрофической развязке трагедии. Данные категории сами по себе являются символическими образованиями, что сделало их предметом постоянных споров эстетиков, а такие споры - принципиально незавершаемыми, ибо их предметом стало то, что подразумевает смысловую бесконечность и существует вместе с ней: «Абсолютное постигается не с помощью символа, а в символе», - писал В. Франкл [7, с. 128]. Благодаря катарсису монотемой трагедии становится не «монотема смерти», как предлагал считать Л. Выготский [4], а монотема бессмертия...

Исходя из изложенного, приходим к выводу, что критерием репертуарного выбора в творческой системе оперного театра, наряду с привлечением произведений, представляющих триединство эпического, лирического и драматического эстетических модусов, является катарсическая оценка. Данная оценка указывает на качество художественного воздействия, необходимое для того, чтобы все составляющие сложного оперного действия, с его и содержательной, и формально-организующей стороны, обрели жанровую завершенность и стилевую убедительность.

Таким образом, современная оперная практика должна базироваться на таком репертуаре, который позволяет реализовывать эстетическое предназначение оперного жанра, а возможные различные репертуарные инновации проверять аналитическим опероведческим путем.

\section{СПИСОК ЛИТЕРАТУРЫ}

1. Богатырев В. Оперное творчество певца-актера : историко-теоретические и практические аспекты : дис. ... доктора искусствоведения : 17.00.09 / Богатырев Всеволод Юрьевич; [Место защиты: С.-Петерб. гуманитар. ун-т профсоюзов]. - Санкт-Петербург, 2011. - 335 с. 
2. Бахтин М. Автор и герой в эстетической деятельности // Эстетика словесного творчества / сост. С. Бочаров ; прим. С. Бочарова и С. Аверинцева] ; М. М. Бахтин. - 2-е изд. - М. : Искусство, 1986. - С. 9-191.

3. Выготский Л. История развития высших психических функций / Л. С. Выготский // [Собр. соч. : в 6 томах]. - М. : Педагогика, 1983. - Т. 3. C. 5-328.

4. Выготский Л. Психология искусства / Л. Выготский. - М. : Искусство, 1968.

5. Лосев А. Строение художественного мироощущения / А. Лосев // А. Ф. Лосев. Форма - Стиль - Выражение. - М. : Мысль, 1995. - С. 297320.

6. Флоренский П. Из богословского наследия / П. Флоренский // Богословские труды. - М., 1977. - Т. ХVII. - С. 85-248.

7. Франкл В. Человек в поисках смысла : [пер. с англ. и нем. / вступ. ст. А. Леонтьева]. - М. : Прогресс, 1990. - 367 с.

Чжан Кай. Репертуарність як критерій сучасної оперної практики. Пропонується розглядати оперний репертуар як необхідну основу діяльності сучасного оперного театру, знаходити у понятті репертуару провідну категорію оперознавства. Визначаються репертуарні константи сучасної оперної творчості, традиційні та інноваційні напрями оперного репертуару. Виводиться критерій репертуарності як показник успішності оперної творчої практики.

Ключові слова: оперний театр, сучасна оперна практика, репертуар, оперознавство, репертуарні інновації.

Chzhan Kay. Repertory is as a criterion of modern opera practice. It is suggested to examine an opera repertoire as necessary basis of activity of modern opera theater, find the leading category of confutation in the concept of repertoire. The repertoire constants of modern opera work, traditional and innovative directions of opera repertoire, are determined. The criterion of repertory is as index of success of opera creative practice hatches.

Key words: opera theater, modern opera practice, repertoire, repertoire innovations. 